\title{
Nitric Oxide Synthase Is Not a Constituent of the Antimicrobial Armature of Human Mononuclear Phagocytes
}

\author{
Markus Schneemann, Gabriele Schoedon, Simone Hofer, \\ Nenad Blau, Lourdes Guerrero, and Andreas Schaffner
}

\author{
Clinical Mrologl Laborator, Division of Infectious Diseases, \\ Department of Medicine, University of Zurich Medical School, Switzerland
}

\begin{abstract}
Nitric oxide synthase (NOS) has received immense interest as an antimicrobial and antitumoral effector system of mononuclear phagocytes from rodents. Because there is increasing doubt that an analogous system exists in human macrophages, NOS was reexamined in these cells. Under tightly controlled conditions, with murine macrophages as positive controls, human macrophages failed to secrete nitric oxide $\left(<0.1 \mu \mathrm{mol} / 10^{6}\right.$ cells $\left./ 24 \mathrm{~h}\right)$, even after activation with endotoxin, interferon- $\gamma$, granulocyte-macrophage colony-stimulating factor, tumor necrosis factor- $\alpha$, bacteria, or proliferating lymphocytes. The discrepancy between murine and human macrophages depended on neither the anatomic source (blood, peritoneum), the agent used for activation, nor the duration of activation. NOS activity was paralleled by metabolization of $L$-arginine to L-citrulline. Exogenous tetrahydrobiopterin, an essential cofactor of NOS not synthesized by human macrophages, did not support NOS activity in human macrophages. Also, no NOS activity was found in cellular subfractions of human macrophages. It appears that in humans, the inducible high-output NOS is not conserved as an antimicrobial system of macrophages.
\end{abstract}

Nitric oxide (NO) has recently been brought into focus as an antimicrobial and antitumoral effector system of mononuclear phagocytes with activity against fungi $[1,2]$, bacteria $[3$, 4], parasites [5-8], and tumor cells [9-15]. While there is general agreement that phagocytes from mice and rats synthesize abundant NO from L-arginine [1, 7, 16-19], demonstration of high-output NO synthase (NOS) activity in human mononuclear phagocytes remains controversial. On one hand, it has been proposed that the antimicrobial activity of human blood-derived macrophages, seen after prolonged activation against Mycobacterium avium-Mycobacterium intracellulare [3] or Trypanosoma cruzii [20], depends on NO. On the other hand, human peritoneal, alveolar, and bloodderived macrophages have not been found to secrete substantial amounts of NO [2 I-24], even after treatment with endotoxin (lipopolysaccharide, LPS) and interferon- $\gamma$ (IFN$\gamma$ ). Also nitrite, a descendant of NO that is unstable under physiologic conditions, was not detectable in supernatants from human macrophages stimulated with LPS and IFN- $\gamma$ [23-25]. Furthermore, alveolar and peritoneal macrophages have not been found to metabolize appreciable amounts of L-arginine, the substrate of NOS [21].

Because of the significance attributed to the effector function of NO produced by mouse and rat macrophages [26-28]

\footnotetext{
Received 16 November 1992: revised I February 1993.

Presented in part: annual meeting of the American Federation for Clinical Research. Baltimore, 1-4 May 1992.

Grant support: Swiss National Science Foundation (32-26411); Bonizzi-

Theler Foundation. L.G. was a scholar of the Swiss Federation.

Reprints or correspondence: Dr. A. Schaffner, Dept. of Medicine AA23. University Hospital, CI1-8091 Zurich, Switzerland.
}

The Journal of Infectious Diseases 1993;167:1358-63 (c) 1993 by The University of Chicago. All rights reserved. 0022-1899/93/6706-0014\$01.00 and the continuous efforts put into studies of NOS in mononuclear phagocytes $[8,20,29-32]$, we decided to reexamine NOS activity in human macrophages.

\section{Materials and Methods}

Phagocytes. Human mononuclear cells were isolated from heparinized blood of normal volunteers by a Ficoll gradient (Pharmacia, Uppsala, Sweden), and lymphocytes were washed away after adhesion of the mononuclear phagocytes to the bottoms of culture wells, giving a monocyte preparation of $>95 \%$ purity as determined by Giemsa stain [33]. Human peritoneal macrophages were obtained by centrifugation, washing, and adhesion purification of dialysate from patients undergoing chronic peritoneal dialysis or with malignant ascites. Mouse peritoneal macrophages were obtained from female 8- to 10-weekold ICR, BALB/c (Institut für Tierzucht, University of Zurich), or $\mathrm{C} 3 \mathrm{H} / \mathrm{HeN}$ mice (WIGA, Sulzfeld, Germany) as resident cells or collected 5-6 days after stimulation with $2 \mathrm{~mL}$ of $10 \%$ thioglycolate broth (Difco, Detroit) or 2\% starch (Merck, Zurich) by lavage with $10 \mathrm{~mL}$ of cold Gey's balanced salt solution (GIBCO Europe, Basel, Switzerland) supplemented with 10 units $/ \mathrm{mL}$. heparin (Hoffmann La Roche, Basel). Blood-derived (heparinized blood, Ficoll) and thioglycolate-induced $(20 \mathrm{~mL} / \mathrm{rabbit})$ peritoneal macrophages were obtained from 2-kg New Zealand White rabbits (Madöring, Füllinsdorf, Switzerland), and mononuclear phagocytes were prepared as described above.

Cell cultures. Mononuclear phagocytes were cultured in 24or 6-well cluster plates (Falcon Plastics, Oxnard, CA) for measurement of NO secretion, NOS, amino acid metabolism, or biopterin synthesis. Phagocytes were seeded at a density of $0.4-$ $0.5 \times 10^{5}$ mononuclear phagocytes $/ \mathrm{cm}^{2}$ of culture surface and cultured with $1 \mathrm{~mL}$ of medium $/ 10^{6}$ cells. Medium 199 (GIBCO) was supplemented with $15 \%$ fetal calf serum (GIBCO) for mice and $20 \%$ human or $20 \%$ rabbit serum for human or rabbit phagocytes, respectively, in addition to $500 \mu \mathrm{mol} \mathrm{L}$-arginine (Fluka, 
Buchs. Switzerland) and $50 \mu \mathrm{g} / \mathrm{mL}$ gentamycin (Schering, Kenilworth. NJ). Medium was changed every $48 \mathrm{~h}$.

Crtokines, hormones, and stimulants. Human recombinant IFN- $\gamma$ was from Biogen (Geneva), recombinant granulocytemacrophage colony-stimulating factor (GM-CSF) from Schering, recombinant tumor necrosis factor- $\alpha$ (rTNF $\alpha$ ) from Knoll (Ludwigshaven. Germany), and recombinant human interleukin-2 (rIL-2) from Hoffmann La Roche. Mouse recombinant IFN- $\gamma$ was a gift of $\mathrm{K}$. Frei (Institute for Clinical Immunology, University of Zurich). LPS (Escherichia coli O26:B6, Boivin extraction) was from Difco: purified protein derivative (PPD) for in vitro use was from the Statens Serumsinstitut (Copenhagen). All supplements were directly dissolved and diluted in medium 199 with the exception of tetrahydrobiopterin $\left(\mathrm{BH}_{4}\right.$; B. Schircks I aboratories, Jona, Switzerland), which was dissolved in $0.05 \mathrm{M}$ $\mathrm{HCl}$ as a $100 \mathrm{~m} M$ stock solution. In some experiments, heatkilled bacteria $\left(10^{8} / \mathrm{mL}\right)$ of Listeria monocytogenes (strain EGD) or Moraxella catarhalis (gift of R. Keller, Arbeitsgruppe für Immunbiologie, University of Zurich Medical School) were used to induce NOS [34].

Quantitation of nitrite. To $150 \mu \mathrm{L}$ of Griess reagent $(0.05 \%$ $N$-1-naphthylethylenediamine dihydrochloride, $0.5 \%$ sulfanilamide $2.5 \%$ phosphoric acid), $50 \mu \mathrm{L}$ of supernatant from macrophage cultures was added and incubated at room temperature for $10 \mathrm{~min}$ in a 96-well microplate (Dynatech, Kloten Switzerland). Absorbance was read at $570 / 630 \mathrm{~nm}$ in a MicroELISA Autoreader MR 580 (Dynatech). Sodium nitrite was used as $\mathrm{NO}_{2}^{-}$standard diluted in complete medium, and the measured amount of $\mathrm{NO}_{2}^{-}$was related to the number of cells in the corresponding well. Cell counts were obtained electronically by a counter (Coulter, Hialeah, FL) as described [33, 35]. Under these conditions, the detection limit was $0.1 \mu M$ nitrite $/ 10^{6}$ cells or $10 \mathrm{pmol} / \mathrm{microwell}$. Activation of human macrophages by cytokines was assessed by monitoring antilisterial activity and $\mathrm{H}_{2} \mathrm{O}_{2}$ secretion by methods described previously [35].

Assay for NOS. Macrophage monolayers from 6-well cluster plates $(35 \mathrm{~mm})$ were washed twice with $15 \mathrm{~m} M$ HEPES, $\mathrm{pH} 7.5$, and were harvested by scraping in $500 \mu \mathrm{L}$ of the same buffer containing $1 \mathrm{mg} / \mathrm{mL} 2$-macroglobulin. Then $50 \mathrm{~mL}$ of this suspension was collected for determination of cell numbers (see above). Cells were disrupted by sonication and centrifuged for $30 \mathrm{~min}$ at $50,000 \mathrm{~g}$ at $4^{\circ} \mathrm{C}$. NOS activity in the supernatants was measured as described [34] with the following modifications: The reaction mixture contained $15 \mathrm{~m} M$ HEPES, pH 7.5, $1 \mathrm{~m} M$ $\mathrm{MgCl}_{2}, 1 \mathrm{~m} M$ dithioerythritol (DTE), $60 \mu M \mathrm{BH}_{4}, 0.1 \mathrm{~m} M$ NADPH, $1 \mathrm{~m} M$ L-arginine, and macrophage lysate in a total volume of $300 \mu \mathrm{L}$. The mixture was incubated in the dark at $37^{\circ} \mathrm{C}$ for $6 \mathrm{~h}$. The reaction was stopped by freezing at $-70^{\circ} \mathrm{C}$. Samples were assayed for nitrite formation using the Griess reaction as described above. Then $100 \mu \mathrm{L}$ of the assay mixture was incubated with $100 \mu \mathrm{L}$ of Griess reagent and read against a sodium nitrite standard dissolved in $15 \mathrm{~m} M$ HEPES, pH 7.5, containing $\mathrm{MgCl}_{2}$, DTE, NADPH, and L-arginine at concentrations used in the assay mixture.

Amino acid analysis. Amino acid contents in macrophage culture supernatants were quantitated by a routine procedure using an LC 5001 Autoanalyzer equipped with BTC 2710 cation exchange resin (Biotronik, Maintal, Germany). Samples
Table 1. Comparison of nitrite $\left(\mathrm{NO}_{2}^{-}\right)$secretion by macrophages from different species and anatomic sources.

\begin{tabular}{|c|c|c|}
\hline Cell source & $\begin{array}{l}\text { Pretreatment } \\
\quad \text { for } 48 \mathrm{~h}\end{array}$ & $\begin{array}{c}\mathrm{NO}_{2}^{-}\left(\mu \mathrm{mol} / 10^{6}\right. \\
\text { cells/day })\end{array}$ \\
\hline \multirow[t]{5}{*}{ Human blood } & None & $<0.1$ \\
\hline & LPS & $<0.1$ \\
\hline & IFN- $\gamma$ & $<0.1$ \\
\hline & IFN- $\gamma+$ LPS & $<0.1$ \\
\hline & IFN- $\gamma+\mathrm{LPS}+\mathrm{BH}_{4}$ & $<0.1$ \\
\hline \multirow[t]{4}{*}{ Human peritoneal } & None & $<0.1$ \\
\hline & LPS & $<0.1$ \\
\hline & IFN- $\gamma+$ LPS & $<0.1$ \\
\hline & $\mathrm{IFN}-\gamma+\mathrm{LPS}+\mathrm{BH}_{4}$ & $<0.1$ \\
\hline \multirow[t]{3}{*}{ Mouse resident } & None & $1.9 \pm 0.4$ \\
\hline & LPS & $5.5 \pm 0.1$ \\
\hline & IFN- $\gamma$ & $59.9 \pm 5.0$ \\
\hline \multirow[t]{5}{*}{ Mouse thioglycolate } & None & $1.8 \pm 0.4$ \\
\hline & LPS & $10.5 \pm 1.3$ \\
\hline & IFN- $\gamma$ & $44.3 \pm 4.4$ \\
\hline & IFN- $\gamma+$ LPS & $51.3 \pm 4.4$ \\
\hline & $\mathrm{IFN}-\gamma+\mathrm{LPS}+\mathrm{BH}_{4}$ & $54.7 \pm 1.5$ \\
\hline \multirow[t]{4}{*}{ Mouse starch } & None & $6.64 \pm 1.4$ \\
\hline & LPS & $15.6 \pm 2.2$ \\
\hline & IFN- $\gamma$ & $25.5 \pm 2.2$ \\
\hline & IFN- $\gamma+$ LPS & $38.3 \pm 2.9$ \\
\hline \multirow[t]{2}{*}{ Rabbit blood } & None & $<0.1$ \\
\hline & LPS & $<0.1$ \\
\hline \multirow[t]{2}{*}{ Rabbit thioglycolate } & None & $<0.1$ \\
\hline & LPS & $<0.1$ \\
\hline
\end{tabular}

NOTE. Human peritoneal macrophages were from peritoneal dialysate fluid ( 1 experiment) or from inflammatory ascites ( 2 experiments). Peritoneal macrophages from rodents were either resident or obtained after intraperitoneal stimulation with $10 \%$ thioglycolate or $2 \%$ starch. Data are mean \pm SE from triplicate experiments. LPS. Escherichia coli endotoxin (lipopolysaccharide), $200 \mathrm{ng} / \mathrm{mL}$ : IFN- $\gamma$, recombinant interferon- $\gamma$ from corresponding species, 100 units $/ \mathrm{mL}: \mathrm{BH}_{4}$, tetrahydrobiopterin, $0.5 \mathrm{mmol}$.

were deproteinated by centrifugation through Ultrafree-MC NMWL filter units with a cutoff of 10,000 Da (Millipore, Bedford, MA). Analysis was developed by a stepwise gradient of lithium citrate ranging from 0.15 to $1.4 \mathrm{~N} \mathrm{Li}$. Amino acids were quantitated by the ninhydrin reaction at 570 and $440 \mathrm{~nm}$.

\section{Results}

When we compared the amount of NO secreted by human, murine, or lapine mononuclear phagocytes, we found in five independent experiments that macrophages from mice but not from humans or rabbits secreted NO in amounts detectable by quantification of nitrite in culture supernatants (table 1). Human and lapine mononuclear phagocytes consistently failed to build up detectable nitrite concentrations in culture supernatants, even after stimulation with LPS or IFN- $\gamma$, while the same stimuli resulted in a 2.5to 30-fold increase of nitrite concentrations in supernatants from murine peritoneal macrophages. To control for activation of human macrophages, listericidal and $\mathrm{H}_{2} \mathrm{O}_{2}$ activity 


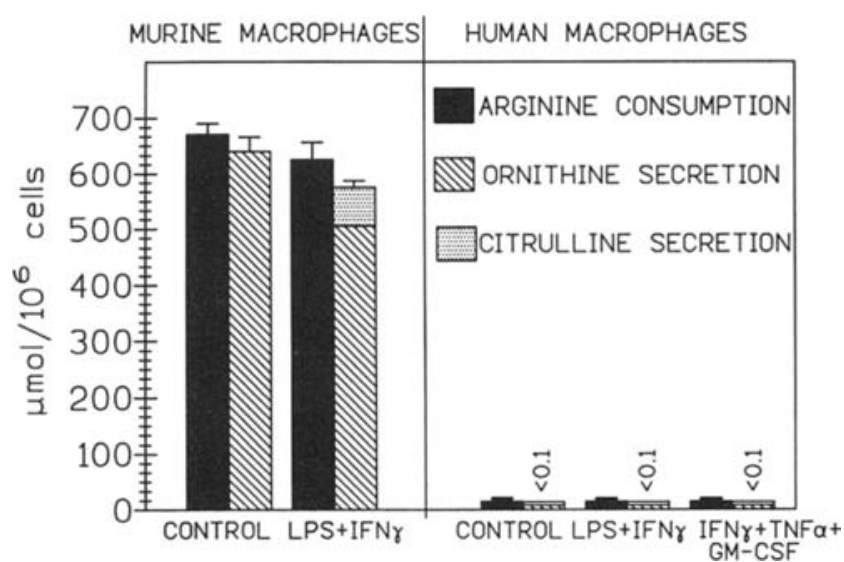

Figure 1. Comparison of consumption of L-arginine and release of ornithine and citrulline into culture medium by mouse peritoneal and human blood-derived macrophages. Endotoxin (lipopolysaccharide, LPS), $200 \mathrm{ng} / \mathrm{mL}$; interferon- $\gamma($ IFN- $\gamma$ ), 100 units $/ \mathrm{mL}$; granulocyte-macrophage colony-stimulating factor (GM-CSF), $100 \mathrm{ng} / \mathrm{mL}$; tumor necrosis factor- $\alpha$ (TNF $\alpha$ ), 100 units $/ \mathrm{mL}$. Concentrations measured in $48-\mathrm{h}$ culture supernatants (mean $\pm \mathrm{SD}$ from triplicate wells).

were monitored after treatment with IFN- $\gamma$ and LPS. Activated cells showed an increase of $\mathrm{H}_{2} \mathrm{O}_{2}$ secretion by a factor of 4-9 and of listericidal activity by a factor of 2-5 (not shown).

The difference between the NOS activity of human, lapine, and murine macrophages did not appear to depend on the anatomic source of the phagocytes, because not only blood-derived but also peritoneal macrophages from humans and rabbits gave equivalent results (table 1). Also, when peritoneal cells were tested, there was no interspecies difference in whether mouse or rabbit macrophages were elicited or resident or in human cells whether macrophages were obtained from peritoneal dialysate fluid or from inflammatory ascitic effusions (table 1).

Because human mononuclear phagocytes did not synthesize tetrahydrobiopterin $\left(\mathrm{BH}_{4}\right)$, an essential cofactor of NOS, we investigated also whether supplementation of exogenous $\mathrm{BH}_{4}$ would give rise to the secretion of NO by human macrophages. Even under these conditions, no NO was produced by human cells (table 1).

Next we studied whether stimuli other than LPS or IFN- $\gamma$, known to activate macrophages, would induce NOS activity in human mononuclear phagocytes or whether a prolonged stimulation for up to 12 days would be effective. Stimulation with IFN- $\gamma$ (at 100 units/mL), IFN- $\gamma$ plus LPS $(200 \mathrm{ng} / \mathrm{mL}$ ), IFN- $\gamma$ plus LPS plus $\mathrm{BH}_{4}(0.5 \mathrm{mmol})$, GM-CSF (100 ng/ $\mathrm{mL}$ ), GM-CSF plus TNF $\alpha$ (100 units $/ \mathrm{mL}$ ), GM-CSF plus IFN- $\gamma$, or GM-CSF plus TNF $\alpha$ plus IFN- $\gamma$ for up to 12 days did not induce any detectable nitrite secretion $(<0.1 \mu \mathrm{mol} /$ $10^{6}$ cell/day). Similarly stimulation with $10^{8}$ heat-killed Listeria monocytogenes or Moraxella catarhalis, both potent stimuli of high-output NOS in murine macrophages [34, 36], or a complete effector system of cell-mediated immunity consisting of autologous sensitized lymphocytes, PPD, and Il-2 [33] completely failed to induce NOS activity. In contrast, the same stimuli studied in parallel provoked nitrite production of 16-54 $\mu \mathrm{mol} / 10^{6}$ cells $/ 24 \mathrm{~h}$ in thioglycolateelicited murine macrophages.

It has been speculated that the failure to demonstrate $\mathrm{NO}$ production by human mononuclear phagocytes in vitro might represent an in vitro artifact because cytokines were found to augment urinary nitrate output in humans [22]. On the basis of such speculations, one could consider the possibility that nitrite measurement in culture supernatants would not be appropriate to detect NO production by human macrophages, for example because NO would be quenched and would not transform to nitrite. To exclude this possibility, we followed the fate of L-arginine, the substrate of NOS, in human and murine macrophages. Neither blood-derived nor peritoneal human macrophages consumed substantial amounts of L-arginine compared with murine macrophages, even after full stimulation with LPS, IFN- $\gamma$, GM-CSF, or TNF $\alpha$, and accordingly produced neither NO nor citrulline, the deamination product of NOS (figures 1,2). Furthermore, human mononuclear phagocytes, as distinct from murine macrophages, also did not metabolize detectable amounts of L-arginine in the urea cycle to ornithine and urea (figures 1 , 2). When we compared quantitatively the consumption of L-arginine by human macrophages to that of 18 other amino acids, we found that L-arginine (which was purposely enriched in culture medium) was not consumed by human macrophages in excess of other amino acids. This indicates that L-arginine was principally used by human phagocytes for protein synthesis. Also in this respect, human cells contrasted with murine macrophages, which consumed $50-80$

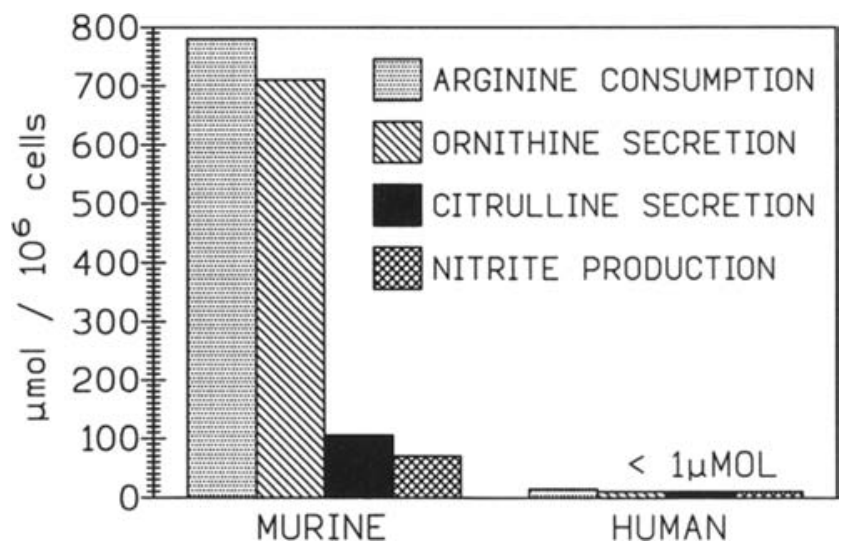

Figure 2. Comparison of $\mathbf{L}$-arginine consumption, ornithine, citrulline, and nitrite secretion by human and murine peritoneal macrophages stimulated by combination of $200 \mathrm{ng} / \mathrm{mL}$ endotoxin and 100 units $/ \mathrm{mL}$ interferon- $\gamma$ for $48 \mathrm{~h}$. Concentrations measured in 48-h culture supernatants (mean from duplicate wells). 
Table 2. Summary of differences between NOS activity, tetrahydrobiopterin synthesis, and L-arginine metabolism in human and murine macrophages.

\begin{tabular}{|c|c|c|}
\hline $\begin{array}{l}\text { Parameter } \\
\left(\text { per } 10^{6} \text { cells } / 24 \mathrm{~h}\right)\end{array}$ & $\begin{array}{c}\text { Murine } \\
\text { macrophages }\end{array}$ & $\begin{array}{c}\text { Human } \\
\text { macrophages }\end{array}$ \\
\hline Nitrite secretion ( $\mu \mathrm{mol})$ & $2-60$ & $<0.1$ \\
\hline $\mathrm{L}$-arginine consumption ( $\mu \mathrm{mol})$ & $600-800$ & $10-20$ \\
\hline Citrulline production $(\mu \mathrm{mol})$ & Up to 60 & $<0.1$ \\
\hline Ornithine production ( $\mu \mathrm{mol})$ & $500-700$ & $<0.1$ \\
\hline Urea production $(\mu \mathrm{mol})$ & $800-1100$ & $<0.1$ \\
\hline $\begin{array}{c}\text { Cytosolic NOS activity } \\
\left(\mu \mathrm{mol} / 10^{6} \mathrm{cells} / \mathrm{h}\right)\end{array}$ & $1.4-2.2$ & $<0.3$ \\
\hline $\begin{array}{l}\text { Cylosolic tetrahydrobiopterin } \\
(\mathrm{pmol} / \mathrm{mg})\end{array}$ & $10-90$ & $<0.03$ \\
\hline
\end{tabular}

NOTE. Cytosolic NOS activity was measured in duplicate experiments with cell lysates from activated ( 100 units of interferon $-\gamma / \mathrm{mL}$ and $200 \mathrm{ng}$ of endotoxin $/ \mathrm{mL}$ for $48 \mathrm{~h})$ and nonactivated cells and $\left(5 \times 10^{7}\right.$ human and murine macrophages/assay). Lower values were from nonactivated cells. higher values from activated cells. No activity was found in vesicular fraction of murine and human cells or total lysates from human cells. Sensitivity level of assay was $0.3 \mu \mathrm{mol} / 10^{6} \mathrm{cells} / \mathrm{h}$. Comparison of cytosolic tetrahydrobiopterin, essential cofactor of NOS, is from [38, 39].

times more L-arginine than any of the other L-amino acids (not shown).

Finally, we turned to a direct measurement of NOS activity in cell lysates and subcellular fractions of human and murine macrophages. In a system in which NADPH and $\mathrm{BH}_{4}$, two essential cofactors of NOS, as well as the substrate L-arginine are supplied in optimal concentrations [37], we were unable to detect NOS activity in subcellular fractions of human macrophages, while murine macrophages consistently showed NOS activity that increased after induction by LPS and IFN- $\gamma$ (table 2).

\section{Discussion}

NO has been proposed as an important antimicrobial and antitumoral effector system of mononuclear phagocytes from laboratory animals. More and more observations on antimicrobial and cytotoxic effects of $\mathrm{NO}$ and the regulation of its production by macrophages appear in the literature, reflecting the enormous interest in this effector system (reviewed in [26-28,40]). Our increasing knowledge of the NOS of rodent macrophages contrasts with the scarcity of data on a counterpart of this enzyme system in human mononuclear phagocytes.

Previous studies have cast doubt on the existence of a high-output NOS in human mononuclear phagocytes that could be induced to produce NO in consequential amounts $[21,23-25]$. Only two studies have proposed that human macrophages produce NO by demonstrating nitrite in a micromolar range in supernatants from human blood-derived macrophages stimulated for extended periods with GM-CSF and TNF $\alpha$ [3] or IFN- $\gamma$ combined with TNF $\alpha$ [20]. In those two studies, however, it was not excluded that the terminal oxidases of the microorganisms, cocultured with macrophages, rather than the phagocytes had produced the nitrite recovered from supernatants $[3,20]$.

To end this controversy, we extended previous studies on NOS activity, NO production, and amino acid metabolism in human mononuclear phagocytes. Our attempts to induce macrophages to secrete $\mathrm{NO}$ in detectable amounts $(\leqslant 0.1$ $\mu \mathrm{mol} / 10^{6}$ cells $/ 24 \mathrm{~h}$ ) by activation with LPS, IFN- $\gamma$, TNF $\alpha$, GM-CSF, intact bacteria, or proliferating lymphocytes, all potent stimuli for the induction of NOS in murine or rat macrophages, completely failed, while parallel studies with murine macrophages confirmed previous observations that resident and elicited peritoneal macrophages secret $\mathrm{NO}$ in a micromolar range, an activity that increases after activation up to $40-60 \mu \mathrm{mol} / 10^{6}$ cells $/ 24 \mathrm{~h}$. Even a prolonged activation for up to 12 days was without effect on the capability of human macrophages to produce NO. The disparity between human and murine cells did not depend on the anatomic source of the phagocyte, because human peritoneal cells and blood-derived macrophages, in accordance with previous reports [21, 23], behaved comparably. Furthermore, rabbit mononuclear phagocytes derived from the blood or from the peritoneal cavity concurrently did not produce NO. Accordingly, it has previously been reported that thioglycolate-elicited macrophages from rabbits do not metabolize L-arginine to $\mathrm{NO}$ and citrulline [41].

A failure to detect NOS activity in human mononuclear phagocytes could theoretically be explained by a deficiency of $\mathrm{BH}_{4}$, an essential cofactor of $\operatorname{NOS}[38,39,42]$. Human mononuclear phagocytes lack the enzyme systems required for the complex biosynthesis of $\mathrm{BH}_{4}$ and would, therefore, in clear distinction to murine macrophages, depend on an exogenous $\mathrm{BH}_{4}$ source for $\mathrm{NO}$ synthesis, a hitherto neglected idea. However, even when $\mathrm{BH}_{4}$ was substituted or when macrophages were cultured in the presence of proliferating lymphocytes that could provide $\mathrm{BH}_{4}$ [39], no $\mathrm{NO}$ was produced.

Another explanation for the failure to demonstrate $\mathrm{NO}$ production by human macrophages could be that in contrast to murine systems, for some reasons NO could not be measured as nitrite in culture supernatants. Also, this possibility was excluded by the observation that human blood-derived and peritoneal macrophages, in contrast to murine cells, do not metabolize L-arginine to citrulline.

Finally, the absence of detectable NOS activity in total cell lysates, the cytosol, or the vesicular fraction of activated human macrophages speaks against an artificial deficit in substrate or cofactors of NOS in vitro. This is because all cofactors for maximal enzyme activity are provided in the assay that worked in parallel wells with murine cell lysates (this study) and in lysates of human hepatocytes [43], human cells that indeed have NOS activity.

In summary, these rigidly controlled studies, each accom- 
panied by positive control experiments, showed that human macrophages, even when activated by numerous stimuli, have no NOS compared with the high activity of the inducible high-output NOS in murine macrophages. The failure to document NOS activity in human macrophages has been regarded in the past by some authorities as an in vitro artifact or has prompted speculations on unprecedented cofactors operative in human but not murine NOS in macrophages. These speculations must be strictly limited to macrophages because the in vitro demonstration of inducible high-output NOS activity is not associated with obstacles in human hepatocytes or their lysates [43].

Therefore, it is time to change our assumptions and to accept that human macrophages do not possess the high-output NOS of murine macrophages as they do not possess systems for the synthesis of its important cofactor, $\mathrm{BH}_{4}$. Interspecies variations in the spectrum of nonoxidative killing systems of phagocytes are not without precedent, as shown with the defensin family of antibiotic peptides [44, 45]. We propose that in humans and most probably also in the rabbit, the inducible high-output NOS of macrophages that is operative in several other mammal species is not conserved as an antimicrobial system, possibly because phagocytic killing systems are redundant in mammals.

\section{References}

1. Granger DL, Hibbs JBJ, Perfect JR, Durack DT. Metabolic fate of L-arginine in relation to microbiostatic capability of murine macrophages. J Clin Invest 1990;85:264-73.

2. Granger DL, Hibbs JBJ, Perfect JR, Durack DT. Specific amino acid (L-arginine) requirement for the microbiostatic activity of murine macrophages, J Clin Invest 1988:81:1129-36.

3. Denis $\mathbf{M}$. Tumor necrosis factor and granulocyte macrophage-colony stimulating factor stimulate human macrophages to restrict growth of virulent Mycobacterium avium and to kill avirulent $M$. avium: killing effector mechanism depends on the generation of reactive nitrogen intermediates. J Leukoc Biol 1991;49:380-7.

4. Higginbotham JN. Lin TL. Pruelt SB. Effect of macrophage activation on killing of Listeria monocylogenes. Roles of reactive oxygen or nitrogen intermediates, rate of phagocytosis, and retention of bacteria in endosomes. Clin Exp Immunol 1992;88:492-8.

5. James SL. Glaven J. Macrophage cytotoxicity against schistosomula of Schistosoma mansoni involves arginine-dependent production of reactive nitrogen intermediates. J Immunol 1989;143:4208-12.

6. Roach TI, Kiderlen AF, Blackwell JM. Role of inorganic nitrogen oxides and tumor necrosis factor alpha in killing Leishmania donovani amastigotes in gamma interferon-lipopolysaccharide-activated macrophages from Lshs and Lshr congenic mouse strains. Infect Immun 1991;59:3935-44.

7. Adams LB, Hibbs JBJ. Taintor RR, Krahenbuhl JL. Microbiostatic effect of murine activated macrophages for Toxoplasma gondii. Role for synthesis of inorganic nitrogen oxides from L-arginine, $\mathrm{J} \mathrm{Im}$ munol 1990; 144:2725-9.

8. Oswald IP, Wynn TA. Sher A. James SL. Interleukin 10 inhibits macrophage microbicidal activity by blocking the endogenous production of tumor necrosis factor $\alpha$ required as a costimulatory factor for interferon gamma-induced activation. Proc Natl Acad Sci USA 1992:89:8676-80.
9. Kwon NS. Stuehr DJ. Nathan CF. Inhibition of tumor cell ribonucleotide reductase by macrophage-derived nitric oxide. J Exp Med $1991 ; 174: 761-7$.

10. Keller R, Geiges M, Keist R. L-arginine-dependent reactive nitrogen intermediates as mediators of tumor cell killing by activated macrophages. Cancer Res 1990;50:1421-5.

11. Drapier JC. Wietzerbin J, Hibbs JBJ. Interferon-gamma and tumor necrosis factor induce the L-arginine-dependent cytotoxic effector mechanism in murine macrophages. Eur J Immunol 1988; 18:158792.

12. Stuehr DJ, Nathan CF. Nitric oxide. A macrophage product responsible for cytostasis and respiratory inhibition in tumor target cells. J Exp Med 1989;169:1543-55.

13. Jiang H, Stewart CA, Fast DJ. Leu RW. Tumor target-derived soluble factor synergizes with [FN-gamma and $1 \mathrm{~L}-2$ to activate macrophages for tumor necrosis factor and nitric oxide production to mediate cytotoxicity of the same target. J Immunol 1992;149:2137-46.

14. Hibbs JBJ, Vavrin Z. Taintor RR. L-arginine is required for expression of the activated macrophage effector mechanism causing selective metabolic inhibition in target cells. J Immunol 1987;1 38:550-65.

15. Hibbs JBJ, Taintor RR, Vavrin Z. Macrophage cytotoxicity: role for $L$-arginine deiminase and imino nitrogen oxidation to nitrite. Science 1987;235:473-6.

16. Stuehr DJ, Marletta MA. Induction of nitrite/nitrate synthesis in murine macrophages by $\mathrm{BCG}$ infection, lymphokines, or interferongamma. J Immunol 1987:1 39:5 I 8-25.

17. Di Rosa M. Radomski M, Carnuccio R. Moncada S. Glucocorticoids inhibit the induction of nitric oxide synthase in macrophages. Biochem Biophys Res Commun 1990:172:1246-52.

18. Stuehr DJ. Cho HJ, Kwon NS. Weise MF, Nathan CF. Purification and characterization of the cytokine-induced macrophage nitric oxide synthase: an FAD- and FMN-containing flavoprotein. Proc Natl Acad Sci USA 1991;88:7773-7.

19. Kwon NS, Nathan CF, Gilker C, Griffith OW, Matthews DE, Stuehr DJ. L-citrulline production from $L$-arginine by macrophage nitric $o x-$ ide synthase. The ureido oxygen derives from dioxygen. J Biol Chem 1990;265:13442-5.

20. Munoz-Fernandez MA, Fernandez MA, Fresno M. Activation of human macrophages for the killing of intracellular Trypanosoma cruzi by TNF-alpha and IFN-gamma through a nitric oxide-dependent mechanism. Immunol Lett 1992:33:35-40.

21. Cameron ML, Granger DL. Weinberg JB, Kozumbo W., Koren HS. Iluman alveolar and peritoneal macrophages mediate fungistasis independently of L-arginine oxidation to nitrite or nitrate. Am Rev Respir Dis 1990:142:1313-9.

22. Hibbs JBJ, Westenfelder C. Taintor R, et al. Evidence for cytokinc-inducible nitric oxide synthesis from L-arginine in patients receiving interleukin-2 therapy. J Clin Invest 1992;89:867-77.

23. Murray HW, Teitelbaum RF. L-arginine-dependent reactive nitrogen intermediates and the antimicrobial effect of activated human mononuclear phagocytes. J Infect Dis 1992;165:513-7.

24. James SL, Cook KW. Lazdins JK. Activation of human monocytederived macrophages to kill schistosomula of Schistosoma mansoni in vitro. J Immunol 1990; 145:2686-90.

25. Padgett EL. Pruett SB. Evaluation of nitrite production by human monocyte-derived macrophages. Biochem Biophys Res Commun 1992;186:775-81.

26. Nathan CF, Hibbs JBJ. Role of nitric oxide synthesis in macrophage antimicrobial activity. Curr Opin Immunol 1991;3:65-70.

27. Liew FY, Cox FE. Nonspecific defence mechanism: the role of nitric oxide. Immunol Today 1991:12:A17-21.

28. Nathan C. Nitric oxide as a secretory product of mammalian cells. FASEB J 1992;6:305I-64. 
29. Cho HJ. Xie QW. Calaycay J, et al. Calmodulin is a subunit of nitric oxide synthase from macrophages. J Exp Med 1992;176:599-604.

30. Hevel JM. Marletta MA. Macrophage nitric oxide synthase: relationship between enzyme-bound tetrahydrobiopterin and synthase activity. Biochemistry 1992:31:7160-5.

31. Gazzinelli RT. Oswald IP, James SL. Sher A. IL-10 inhibits parasite killing and nitrogen oxide production by IFN-gamma-activated macrophages. J Immunol 1992:148:1792-6.

32. Mcyer J. Traber LD, Nelson S. et al. Reversal of hyperdynamic response to continuous endotoxin administration by inhibition of NO synthesis. J Appl Physiol 1992;73:324-38.

33. Schaffner A. Therapeutic concentrations of glucocorticoids suppress the antimicrobial activity of human macrophages without impairing their responsiveness to gamma interferon. J Clin Invest 1985; 76:1755-64.

34. Keller R, Gehri R, Keist R. Huf E. Kayser FH. The interaction of macrophages and bacteria: a comparative study of the induction of tumoricidal activity and of reactive nitrogen intermediates. Cell Immunol 1991: 134:249-56.

35. Schaffner A, Rellstab P. Gamma-interferon restores listericidal activity and concurrently enhances release of reactive oxygen metabolites in dexamethasone-treated human monocytes. I Clin Invest 1988; $82: 913-9$.

36. Keller R. Keist R. Frei K. Lymphokines and bacteria, that induce tumoricidal activity, trigger a different secretory response in macrophages. Eur J Immunol 1990;20;695-8.

37. Tayeh MA, Marletta MA. Macrophage oxidation of $L$-arginine to nitric oxide, nitrite, and nitratc. Tetrahydrobiopterin is required as a cofactor. I Biol Chem 1989;264:19654-8.

38. Schoedon G. Troppmair J, Fontana A. Huber C, Curtius HC, Niederwieser A. Biosynthesis and metabolism of pterins in peripheral blood mononuclear cells and leukemia lines of man and mouse. Eur J Biochem 1987; 166:303-10.

39. Schoedon G, Troppmair J, Adolf G, Huber C, Niederwieser A. Interferon-gamma enhances biosynthesis of pterins in peripheral blood mononuclear cells by induction of GTP-cyclohydrolase $\mathbf{I}$ activity. $\mathrm{J}$ Interferon Res 1986:6:697-703.

40. Moncada S, Palmer RM, Higgs EA. Nitric oxide: physiology, pathophysiology, and pharmacology. Pharmacol Rev 1991;43:109-42.

41. Bernard C, Szekely B, Philip I, Wollman E, Payen D, Tedgui A. Activated macrophages depress the contractility of rabbit carotids via an L-arginine/nitric oxidc-dependent effector mechanism. Connection with amplified cytokine release. J Clin Invest 1992;89:851-60.

42. Kwon NS, Nathan CF, Stuehr DJ. Reduced biopterin as a cofactor in the generation of nitrogen oxides by murine macrophages. J Biol Chem 1989;264:20496-501.

43. Nussler AK, Di Silvio M. Billiar TR, et al. Stimulation of the nitric oxide synthase pathway in human hepatocytes by cytokines and endotoxin. J Exp Med 1992;176:261-4.

44. Eisenhauer PB, Lehrer RI. Mouse neutrophils lack defensins. Infect Immun 1992;60:3446-7.

45. Schaffiner A. Host defence in aspergillosis. In: Bennett JE, Hay RJ, Peterson PK, cds. New strategies in fungal disease. Edinburgh: Churchill Livingstone, 1992:98-112. 